\title{
Sintering Temperature and Applied Pressure Effect on Manufacturing Ni-Cr Based Composite Material.
}

\author{
Vilas K. Patil, Udhhav M. Shirsat
}

\begin{abstract}
Mechanical Property of Nickel-Chromium composite investigated with different parameters. Green pallets (composite) were manufactured under the different pressure (220MPa, 275MPa and 330MPa) and such pallet sintering in two different temperatures $\left(900^{\circ} \mathrm{C}\right.$ and $\left.1000^{\circ} \mathrm{C}\right)$. The result indicate that the properties of the composite increases with increasing pressure and also with increasing sintering temperature for $\mathrm{Ni}-\mathrm{Cr}$ based composite. Porosity plays a vital role in mechanical properties of composite and it present between maximum $4.304 \%$ to minimum $1.865 \%$. For highly porous material, mechanical properties are minimum than lower porous composite material. The result of the study reveals that the properties of $\mathrm{Ni}-\mathrm{Cr}$ based composite improved for $330 \mathrm{MPa}$ pressure and $1000^{\circ} \mathrm{C}$ temperature. Thus there is need to consider these aspect while manufacturing the composite material to have a good mechanical or Tribological properties.
\end{abstract}

Keywords: Ni-Cr based material, Green pallet applied pressure, Sintering temperature.

\section{INTRODUCTION}

V arious parameter are decided the Quality of metal composite material. This parameter selection is one of the difficult tasks to any manufacturer, because such parameter effect reflects the quality of final product/ material. For manufacturing metal composite applied pressure is one of the important parameter used for proper bonding of metal composite. This effect reflects the variation is mechanical properties of final material Researchers study the various properties of composite material based on its application or uses. Study the different element content percentage and decide the final composition based on the suitable properties. Another side, researchers have been carried out to study the tribological behaviours of metal composite material at room temperature to high temperature range condition, indicating that the metal composite possesses good tribological properties [1-4]. The aim of this study is to explore the effect

Revised Manuscript Received on February 05, 2020.

* Correspondence Author

Vilas K. Patil*, Research Scholar, Amrutvahini College of Engineering, Sangamner, MH-422608, India. Email: vk.patil@kkwagh.edu.in

Udhhav M. Shirsat, Mechanical Engg. Department Amrutvahini College of Engineering, Sangamner, MH-422608, India. Email: shirsatum@yahoo.com

(C) The Authors. Published by Blue Eyes Intelligence Engineering and Sciences Publication (BEIESP). This is an open access article under the CC BY-NC-ND license (http://creativecommons.org/licenses/by-nc-nd/4.0/) of applied pressure on element powder (composite powder) and study it effect on final properties based on the different sintering temperature zone condition. For improve the mechanical properties of metal composite researchers were used different combination or variation in weight percentages of powder. In this study three different combination of $\mathrm{Ni}-\mathrm{Cr}$ based composite powder percentage used and studies its mechanical properties.

The applied pressure on green die (preparation of powder to pallet) has been study. Such powder pressed under three different pressures $220 \mathrm{MPa}, 275 \mathrm{MPa}$ and $330 \mathrm{MPa}$ respectively. The green pallet sintered at two different batches having $900^{\circ} \mathrm{C}$ and $1000^{\circ} \mathrm{C}$ temperatures. Ni-Cr based metal composite has been prepared and tested under the standard condition and compare it properties.

\section{METHODOLOGY}

\section{A. Manufacturing process (Preparation of composite powder):}

Commercial available powder from supplier as shown table no. 1, having range is $12-25 \mu \mathrm{m}$ or $325 \mathrm{Mesh} 99.9 \mathrm{wt} \%$ purity. As per the final composition of specimen shown in table 01 where added in rotary stainless steel ball mill for milling, with case harden stainless steel ball $(24 \mathrm{~mm}$ in diameter). Here the total time for milling is taken 24 hours. The ratio of ball to powder is taken as 10:1 in weight. The total milling process done in closed air proof chamber, powders where mixed in chamber and milling in Argon (Ar) gas atmosphere with a rotational speed $800 \mathrm{rpm}$. Argon gas is used for avoid the chemical reaction of powder with air.

Table No.01 Weight percentage (\%) of powder specimen

\begin{tabular}{|c|c|c|c|c|c|c|c|c|}
\hline & $\mathrm{Ni}$ & $\mathrm{Cr}$ & $\mathrm{Co}$ & $\mathrm{Si}$ & $\mathrm{Mo}$ & $\mathrm{Cu}$ & $\mathrm{W}$ & PVA \\
\hline S-01 & 27.21 & 49.19 & 12 & 2.75 & 4.6 & 2 & 2 & 0.25 \\
\hline S-02 & 27.21 & 47.54 & 12.25 & 2.75 & 4 & 3 & 3 & 0.25 \\
\hline S-03 & 51.75 & 24 & 12.25 & 1.75 & 5 & 3 & 2 & 0.25 \\
\hline
\end{tabular}

Uniformed mixed powders as shown table no.1 were checked under the microscope for proper mixing of powder elements. Fig 1 and Fig.2 shows that the mixing of alloy powder is done uniformly. 


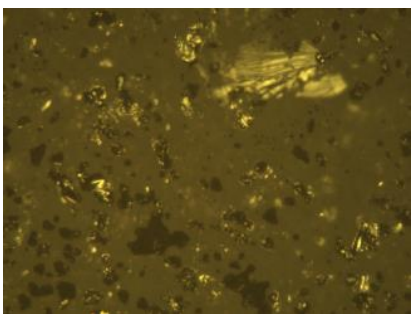

Fig. 1 (Specimen -01)

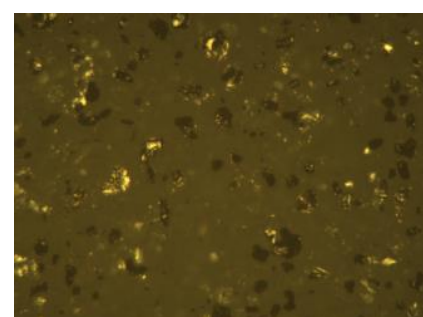

Fig. 2 (Specimen-02)

\section{Powder Mettalography}

The final composition shown in table no.1 are uniformly mixed together with binding agent by using above process, then these final wt\% powder used for preparation of respective specimen. They were pressed as specimen $\varnothing 12.5 \mathrm{~mm} \times 22 \mathrm{~mm}$ as shown fig. 3 with 220MPa (Batch-I), 275MPa (Batch-II) and 330MPa (Batch-III) uniaxial pressure in a steel mould in an ambient temperature. Computerizes Universal testing machine/Press TUF-C-1200(SERVO) having 150T Capacity is used as a Mechanical press as shown fig. 4a and 4b. High finish Stainless Steel 314 material die having $\varnothing 12.5 \mathrm{~mm} \times 60 \mathrm{~mm}$ size has been modified as per the fixture of UTM/Press. For avoid the friction between the pressed powder during cold pressing, the surface of die is highly finished. After preparation of final powder products, specimens were kept in the calibrated muffle furnace. Temperature rise rate of furnace is noted $40^{\circ} \mathrm{C}$ per minute. Furnace temperature noted by thermocouple and such specimen kept in the furnace at room temperature till the temperature is $900^{\circ} \mathrm{C}$ for one batch and $1000^{\circ} \mathrm{C}$ for other batch with holding time is 02 Hours. For avoid the chemical reaction or oxidation of specimen furnace is fully closed and argon gas used as an inert gas.

For study the effect of various parameters of composite material, three batches were prepared for one composition powder (specimen). These composite powders pressed under the 220MPa, 275MPa, and 330MPa pressure respectively for study its mechanical and thermal properties.

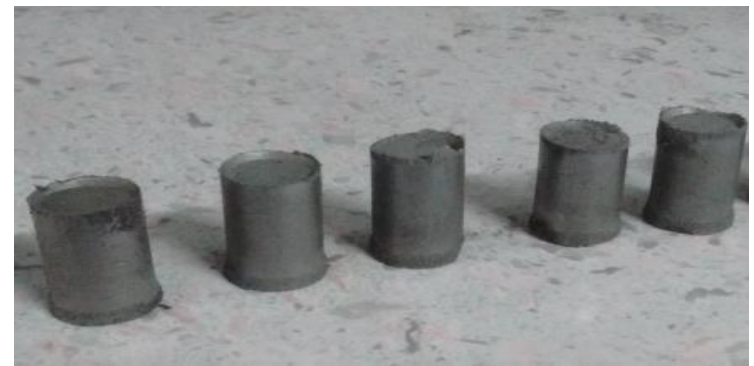

Fig: 3Cold Press Green Specimen
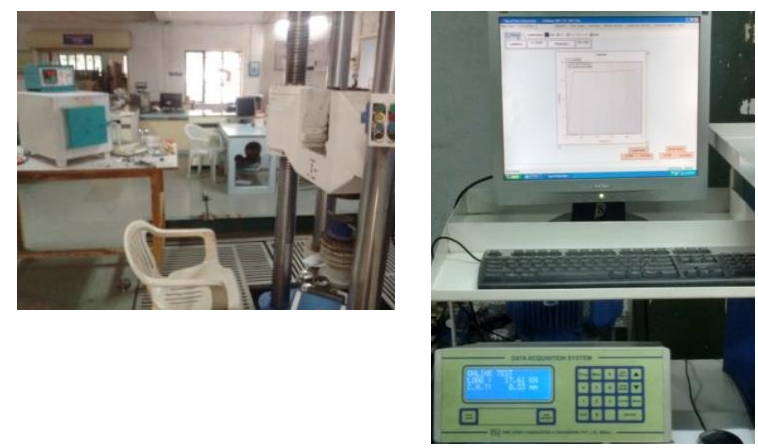

Fig.4a UTM
Fig.4b UTM data acquisition system
Temperature of Muffle furnace has been decided based on the minimum melting point of metal powder. Furnace temperature maintained below the melting point of $\mathrm{Cu}$ and it is stable at $900^{\circ} \mathrm{C}$ and $1000^{\circ} \mathrm{C}$ for different batches.

Manufacturing of green specimen as shown table no.1, three different pressure load conditions are used. Three batches of one specimen developed under 220MPa, 275MPa and 330MPa pressure respectively. Computerized Universal Testing Machine used for applied axial load on die and for prepares the green specimen and it also used for remove the green specimen from die. After every green specimen, pin and die is cleaned by using smooth cotton then used for next specimen.

\section{B. Sintering process:}

Muffle furnace is used for sintering with maximum 1010 ${ }^{0} \mathrm{C}$ temperature capacity. Temperature rise rate for furnace is $10^{\circ} \mathrm{C}$ in open door condition. It is a closed type muffle furnace and Argon gas atmosphere is used. Manufactured Green specimens were kept in furnace at room temperature and time noted for such condition. Then after every 5/10 minutes temperature of furnace is noted. Specimen 01, 02 and 03 has been kept in two different temperatures for sintering. First batch sintering for $1000^{\circ} \mathrm{C}$ temperature condition and second batch is sintering for $900^{\circ} \mathrm{C}$ condition. After reaching the above peak value such temperature kept constant for 2 hours, then it's cool till temperature of furnace down up to $80^{\circ} \mathrm{C}$. Graph 01 shows the sintering temperature zone for $1000^{\circ} \mathrm{C}$ condition, and graph 02 shows the condition of $900^{\circ} \mathrm{C}$. Composite powder pressed under room temperature $\left(28^{0} \mathrm{C}\right)$ for various batches. After manufacturing these green specimens 01, 02 and 03, are kept in furnace for $\left(1000^{\circ} \mathrm{C}\right)$ sintering. The duration between these steps is 43, 24 and 18 hours respectively. Graph 01 shows the detail temperature curve for sintering, from room temperature to $1000^{\circ} \mathrm{C}$ furnace and its take 90 minutes for reaching this temperature. After reaching this temperature its stable for 2 Hours, then it's again taking some time for cool down. After 16 hours temperature of furnace noted $80^{\circ} \mathrm{C}$. All specimens removed from furnace under $80^{\circ} \mathrm{C}$ temperature, and then kept in tray for cooling till room temperature noted.

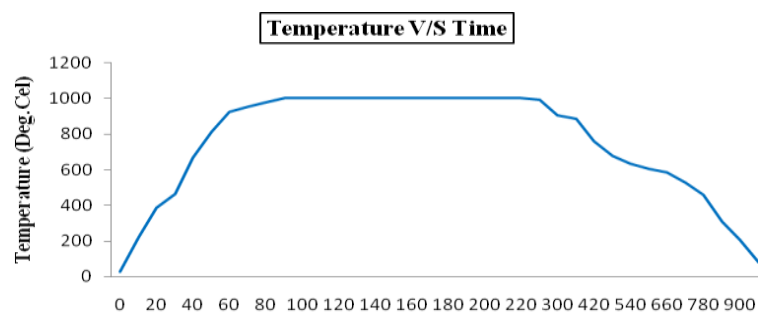
Time (Min.)

\section{Graph 01: Sintering temperature zone for $1000^{\circ} \mathrm{C}$ condition}

Graph 02 shows the detail temperature curve for sintering, from room temperature to $900^{\circ} \mathrm{C}$ furnace take 60 minutes After reaching this temperature its stable for 2 Hours, then it's again taking some time for cool down.

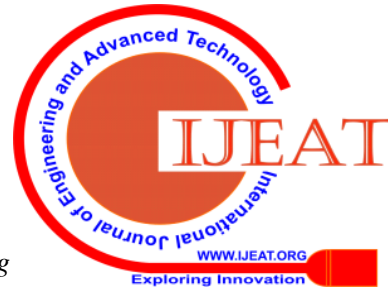
\& Sciences Publication 
Total time for such process is recorded 20Hours, after 20 hours temperature of furnace noted $86^{\circ} \mathrm{C}$. All specimens removed from furnace under $86^{\circ} \mathrm{C}$ temperature, and then kept in tray for cooling till room temperature noted.

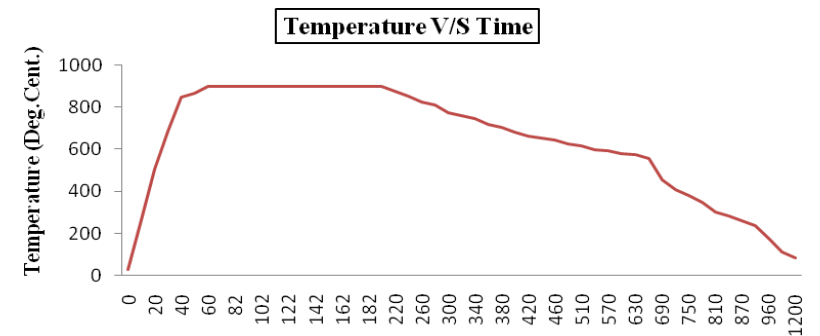

Time (Min.)

Graph 02: Sintering temperature zone for $900^{\circ} \mathrm{C}$ condition

Green specimen number 01, 02 and 03, where kept in furnace for $\left(900^{\circ} \mathrm{C}\right.$ temp.) sintering after 96,76 and 70 hours respectively. During manufacturing green specimen room temperature noted $31^{\circ} \mathrm{C}$.

\section{RESULT AND DISCUSSION}

Before conducting the various tests and calculating its properties, all specimens clean and prepared as per the standard. Microstructure of Ni-Cr base composite specimen observed under optical micrometer.

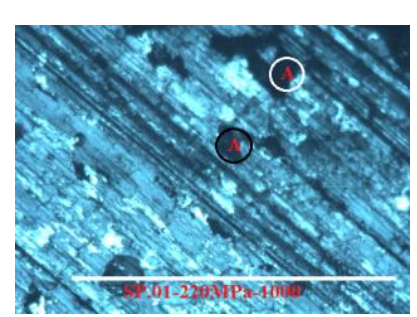

Sp.No.01-Applied

Pressure 220MPa-

Sintering Temperature $1000^{\circ} \mathrm{C}$

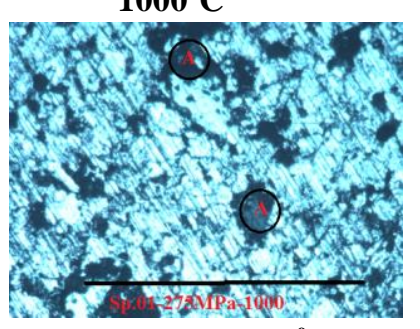

01-275MPa- $1000^{\circ} \mathrm{C}$

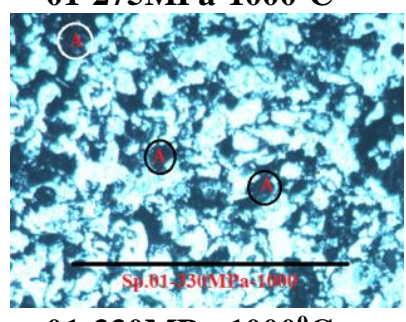

01-330MPa- $1000^{\circ} \mathrm{C}$

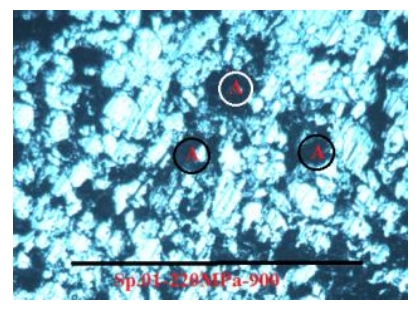

Sp.No.01-Applied Pressure 220MPaSintering Temperature $900^{\circ} \mathrm{C}$

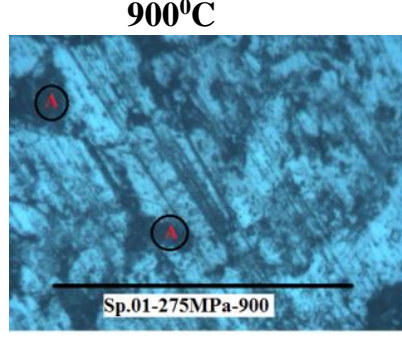

01-275MPa-900 ${ }^{\circ} \mathrm{C}$

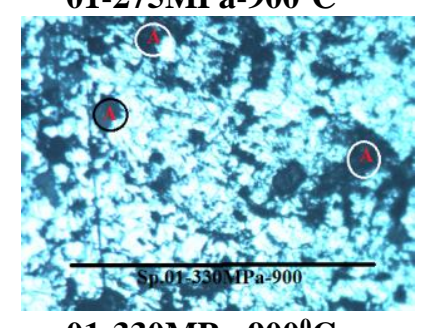

01-330MPa-900 ${ }^{\circ} \mathrm{C}$

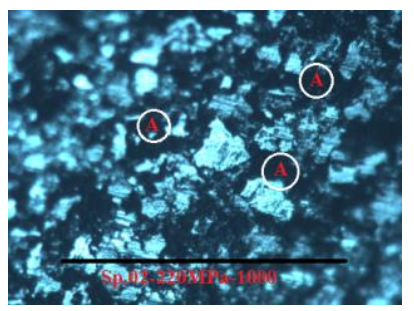

02-220MPa-1000 ${ }^{\circ} \mathrm{C}$

02-275MPa- $1000^{\circ} \mathrm{C}$

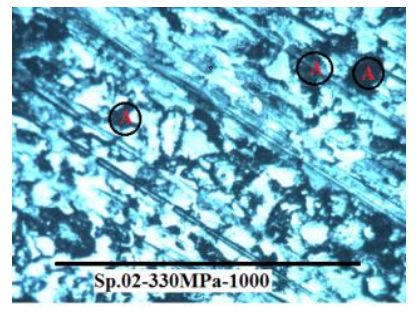

02-330MPa- $1000^{\circ} \mathrm{C}$

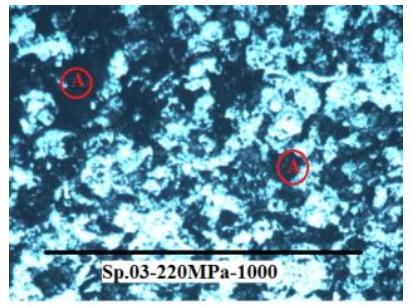

03-220MPa- $1000^{\circ} \mathrm{C}$

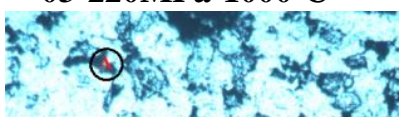
- 12 .

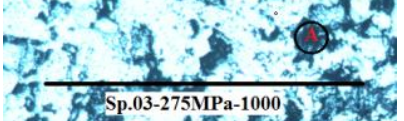

03- 275MPa- $1000^{\circ} \mathrm{C}$

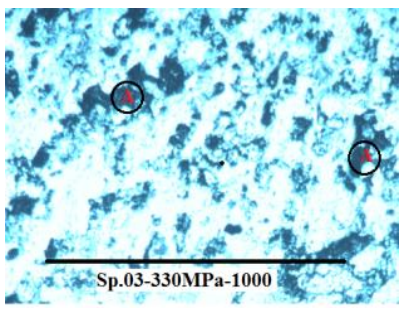

03-330МРa- $1000^{\circ} \mathrm{C}$

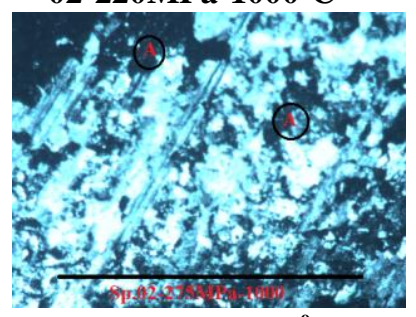
- v) 430 ?

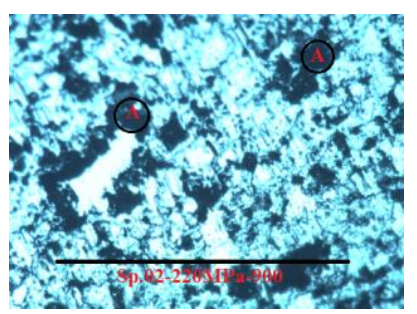

02-220MPa- $900^{\circ} \mathrm{C}$

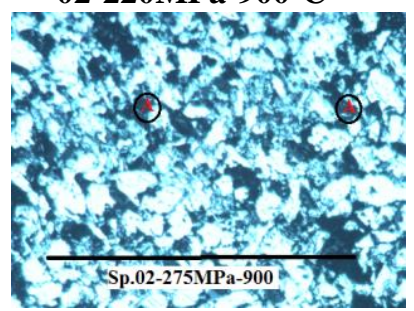

$02-275 \mathrm{MPa}-900^{\circ} \mathrm{C}$

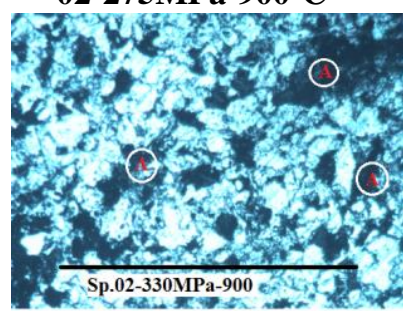

02-330MPa- $900^{\circ} \mathrm{C}$

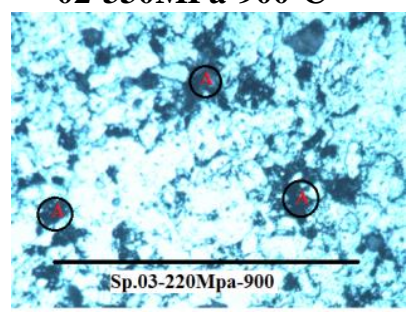

03-220MPa-900 ${ }^{\circ} \mathrm{C}$

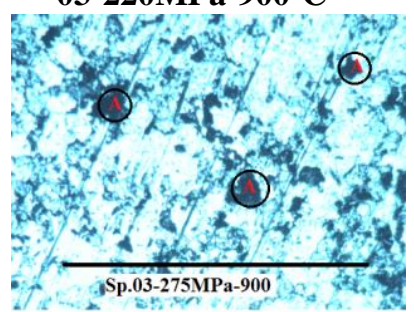

03-275MPa-900 ${ }^{\circ} \mathrm{C}$

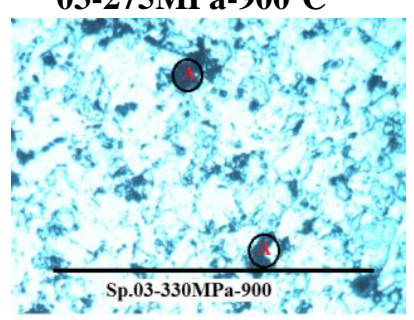

03-330MPa-900 ${ }^{\circ} \mathrm{C}$
In all microstructure fig. of $\mathrm{Ni}-\mathrm{Cr}$ composite zone $\mathrm{A}$ indicate black area and its indicate that the porosity percentages of specimen. Due to the porosity such gap has carbonize under sintering temperature and throughout the structure of specimen is same. For $900^{\circ} \mathrm{C}$ sintering temperature such black zone covered maximum area than $1000^{\circ} \mathrm{C}$ sintering temperature.

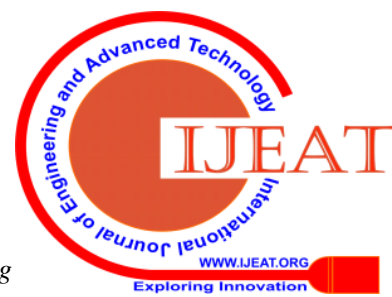


Sintering Temperature and Applied Pressure Effect on Manufacturing Ni-Cr Based Composite Material.

In porosity contents it observed that porosity of specimen decreases if sintering temperature increases, so sintering temperature plays a vital role in this process.

Porosity of specimen calculated based on simple method [5]. Initially the mass of dry specimen is noted, and it's immersed in hot water (temp. $28^{\circ} \mathrm{C}$ ) for 2 hours, After 2 hours specimen take out from water and again noted it mass. Difference between dry and wet specimen is decided the porosity percentage. Table number 02 shows the porosity of different specimens for different applied load and sintering temperature.

Table 02: Porosity percentages for different specimens

\begin{tabular}{c|c|c|r|r}
\hline \multirow{2}{*}{$\begin{array}{c}\text { Specime } \\
\mathrm{n} \text { Number }\end{array}$} & $\begin{array}{c}\text { Sintering } \\
\text { Temp. }\left({ }^{\circ} \mathrm{C}\right)\end{array}$ & $\begin{array}{c}\text { Batch-I } \\
(220 \mathrm{MPa})\end{array}$ & $\begin{array}{r}\text { Batch-II } \\
(275 \mathrm{MPa})\end{array}$ & $\begin{array}{r}\text { Batch-III } \\
(330 \mathrm{MPa})\end{array}$ \\
\cline { 3 - 5 } & 900 & 4.082 & 3.769 & 2.446 \\
\hline \multirow{2}{*}{01} & 1000 & 3.830 & 2.938 & 1.909 \\
\cline { 2 - 5 } & 900 & 4.304 & 3.475 & 2.755 \\
\cline { 2 - 5 } & 1000 & 3.643 & 2.455 & 2.179 \\
\hline \multirow{2}{*}{03} & 900 & 3.962 & 2.562 & 2.155 \\
\cline { 2 - 5 } & 1000 & 3.330 & 2.324 & 1.865 \\
\hline
\end{tabular}

Porosity of Ni-Cr base composite material is less under the $1000^{\circ} \mathrm{C}$ sintering temperature than $900^{\circ} \mathrm{C}$ for all type of load as well as different composition. Minimum porosity present for specimen-03 under 330MPa applied pressure and $1000^{\circ} \mathrm{C}$ sintering temperature.

Modulus of elasticity and Bulk modulus of Ni-Cr based composite material calculate as per the ASME standard. Modulus of Elasticity increases with respect to sintering temperature and Applied pressure load and weight percentage of composite table 3 and table 4 shows the Modulus of Elasticity and bulk modulus respectively.

Table No.3 Modulus of Elasticity (E)

\begin{tabular}{c|c|c|c|c}
\hline \multirow{2}{*}{$\begin{array}{c}\text { Specimen } \\
\text { Number }\end{array}$} & $\begin{array}{c}\text { Sintering } \\
\text { Temp. }\left({ }^{\circ} \mathrm{C}\right)\end{array}$ & $\begin{array}{c}\text { Match- } \\
\text { I }(220)\end{array}$ & $\begin{array}{c}\text { Batch-I } \\
\text { I (275) }\end{array}$ & $\begin{array}{c}\text { Batch-II } \\
\text { I (330) }\end{array}$ \\
\cline { 3 - 5 } & 900 & 153.24 & 185.64 & 207.45 \\
\cline { 2 - 5 } 01 & 1000 & 155.45 & 163.25 & 203.56 \\
\hline \multirow{2}{*}{02} & 900 & 171.23 & 135.26 & 205.63 \\
\cline { 2 - 5 } & 1000 & 173.64 & 184.25 & 173.56 \\
\hline \multirow{2}{*}{03} & 900 & 148.75 & 156.43 & 201.56 \\
\cline { 2 - 5 } & 1000 & 142.23 & 208.15 & 210.55 \\
\hline
\end{tabular}

Specimen01 are manufactured in two batches under three different pressure conditions. Batch $1 \& 2$ sintered for $1000^{\circ} \mathrm{C}$ and $900^{\circ} \mathrm{C}$ sintering temperature. Graph 03 shows that the Modulus of elasticity of specimen 01 increases with increasing applied pressure on green pallet for both sintering temperature condition. For 220MPa load condition modulus of elasticity is less for $900^{\circ} \mathrm{C}$ sintering temperature than $1000^{\circ} \mathrm{C}$ sintering temperature, but for next pressure $275 \mathrm{MPa}$ and $330 \mathrm{MPa}$ condition modulus of elasticity is increases for $900^{\circ} \mathrm{C}$ sintering temperature than $1000^{\circ} \mathrm{C}$ sintering temperature.

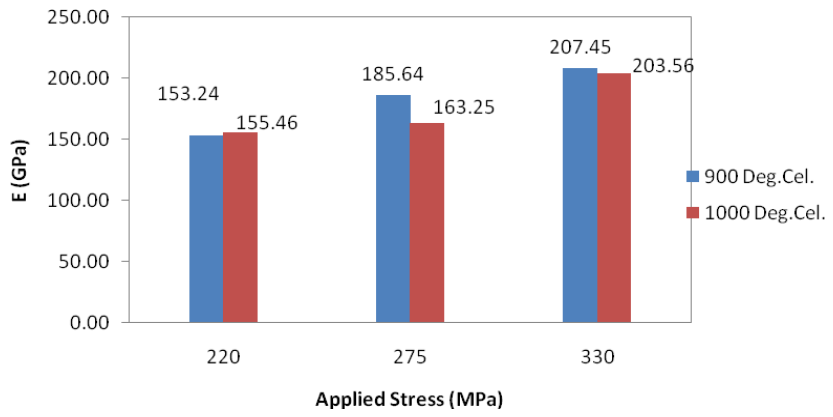

Graph03: Modulus of Elasticity of specimen 01

Specimen02 also manufactured in two batches under three different pressure conditions. Batch $1 \& 2$ sintered for $1000^{\circ} \mathrm{C}$ and $900^{\circ} \mathrm{C}$ sintering temperature. Graph 04 shows that the Modulus of elasticity of specimen 02 is initially $171.24 \mathrm{GPa}$ for 220MPa applied pressure condition, for second condition such value decreases up to $135.26 \mathrm{GPa}$ and it increases up to 205.63GPa for 330MPa applied pressure condition for $900^{\circ} \mathrm{C}$ sintering temperature condition. For $1000^{\circ} \mathrm{C}$ sintering temperature condition such value is $173.65 \mathrm{GPa}, 184.25 \mathrm{GPa}$ and $173.56 \mathrm{GPa}$ respectively for applied pressure $220 \mathrm{MPa}$ ,275MPa \& 330MPa.

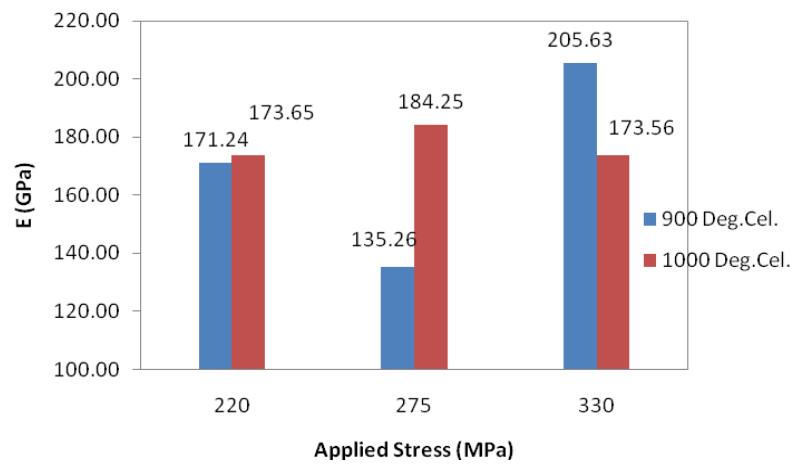

Graph 04: Modulus of Elasticity of specimen 02

Modulus of elasticity of specimen 03 increases with increasing applied pressure on green pallet for both sintering temperature condition. For 220MPa load condition modulus of elasticity is less for $1000^{\circ} \mathrm{C}$ sintering temperature than $900^{\circ} \mathrm{C}$ sintering temperature, but for next pressure $275 \mathrm{MPa}$ and $330 \mathrm{MPa}$ condition modulus of elasticity is increases for $1000^{\circ} \mathrm{C}$ sintering temperature than $900^{\circ} \mathrm{C}$ sintering temperature.

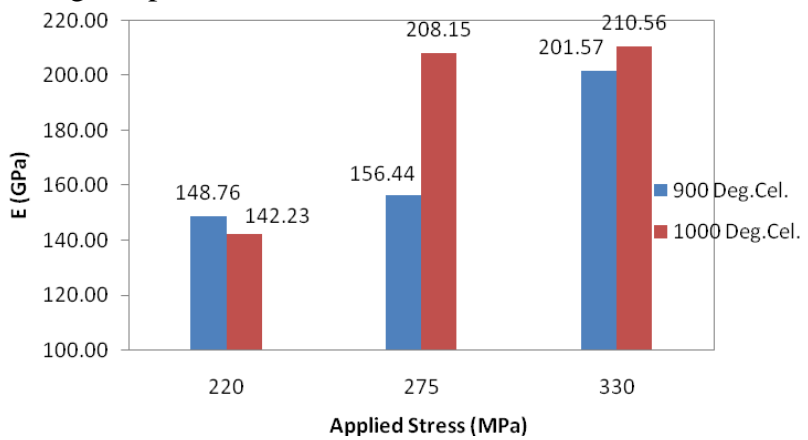

Graph05: Modulus of Elasticity of specimen 03 
Graph trends shows that the modulus of elasticity of $\mathrm{Ni}-\mathrm{Cr}$ base composite material is increases based on applied pressure of green pallet, but it varies based on the sintering temperature.

Table 04: Bulk modulus of Ni-Cr base composite.

\begin{tabular}{c|c|c|c|c}
\hline \multirow{2}{*}{$\begin{array}{c}\text { Specimen } \\
\text { Number }\end{array}$} & $\begin{array}{c}\text { Sintering } \\
\text { Temp. }\left({ }^{\circ} \mathrm{C}\right)\end{array}$ & $\begin{array}{c}\text { Batch- } \\
\text { I (220) }\end{array}$ & $\begin{array}{c}\text { Batch-I } \\
\text { I (275) }\end{array}$ & $\begin{array}{c}\text { Batch-II } \\
\text { I (330) }\end{array}$ \\
\cline { 3 - 5 } & 900 & 94.593 & 116.31 & 130.47 \\
\cline { 3 - 5 } 01 & 1000 & 98.141 & 106.70 & 126.21 \\
\hline \multirow{2}{*}{02} & 900 & 109.76 & 85.07 & 129.52 \\
\cline { 2 - 5 } & 1000 & 109.66 & 114.33 & 107.73 \\
\hline \multirow{2}{*}{03} & 900 & 93.24 & 98.05 & 127.30 \\
\cline { 2 - 5 } & 1000 & 88.12 & 128.96 & 132.98 \\
\hline
\end{tabular}

Bulk modulus is noted for minimum value 85.07GPa for specimen02 for batch-II load condition and for $900^{\circ} \mathrm{C}$ sintering temperature condition, and maximum value noted for specimen 03 for batch-III load condition manufactured under $1000^{\circ} \mathrm{C}$ sintering temperature condition.

Computerized micro hardness tester is used to measure hardness value. Load is applied on a sample for 10 second then the indentation measured from a projection of the indentation on a display gauge. Along the diameter (core) of specimen at least three indentations for hardness measured. Then the average of these readings is reported as the hardness value of respective specimen as per table no.05

Table No.05Hardness of specimen at different distance

\begin{tabular}{|c|c|c|c|}
\hline $\begin{array}{l}\text { Specime } \\
\text { n No. }\end{array}$ & \multicolumn{2}{|c|}{$\begin{array}{l}\text { Hardness } \\
\text { Value }\end{array}$} & Remark \\
\hline & $900^{\circ} \mathrm{C}$ & $1000^{\circ} \mathrm{C}$ & \\
\hline 01 & $\begin{array}{l}76 \\
74 \\
73\end{array}$ & $\begin{array}{l}78 \\
77 \\
76\end{array}$ & $\begin{array}{c}\text { Applied load is 588.6 N } \\
\text { (Rockwell Hardness Tester, } \\
\text { Model-MSM, Sr.No. 2011/146) }\end{array}$ \\
\hline 02 & $\begin{array}{l}128.87 \\
135.79 \\
138.42\end{array}$ & $\begin{array}{l}202.56 \\
204.54 \\
199.68\end{array}$ & Applied load is $1 \mathrm{Kgf}$ for 10 second \\
\hline 03 & $\begin{array}{l}135.1 \\
138.6 \\
236.5\end{array}$ & $\begin{array}{l}199.7 \\
245.4 \\
238.1\end{array}$ & $\begin{array}{l}\text { (Micro Hardness tester, NEC } \\
\text { Laboratory) }\end{array}$ \\
\hline
\end{tabular}

Hardness value of $\mathrm{Ni}-\mathrm{Cr}$ based composite material shows as per table 05 . Porosity plays a vital role in hardness value, highly porosity of material having low Hardness than the minimum porosity of material.

Table 06 shows the detail values of crushing stress (MPa) for all specimens. For specimen 2 minimum stress values present $23.64 \mathrm{MPa}$ for $900^{\circ} \mathrm{C}$ sintering temperature for batch-II. Maximum crushing stress values present for specimen 3 is $300.02 \mathrm{MPa}$ for $1000^{\circ} \mathrm{C}$ sintering temperature for batch-III.

Table 06: Crushing/Compression properties of specimen

\begin{tabular}{c|c|c|c|c}
\hline \multirow{2}{*}{$\begin{array}{c}\text { Specimen } \\
\text { Number }\end{array}$} & \multirow{2}{*}{$\begin{array}{c}\text { Sintering } \\
\text { Temp. }\left({ }^{0} \mathrm{C}\right)\end{array}$} & $\begin{array}{c}\text { Batch- } \\
\text { I (220) }\end{array}$ & $\begin{array}{c}\text { Batch-I } \\
\text { I (275) }\end{array}$ & $\begin{array}{c}\text { Batch-II } \\
\text { I (330) }\end{array}$ \\
\cline { 3 - 5 } & 900 & 57.88 & 74.19 & 145.93 \\
\cline { 2 - 5 } 01 & 1000 & 39.94 & 66.85 & 123.10 \\
\hline \multirow{2}{*}{02} & 900 & 70.11 & 23.64 & 123.11 \\
\cline { 2 - 5 } & 1000 & 61.14 & 85.60 & 77.45 \\
\hline \multirow{2}{*}{03} & 900 & 48.10 & 66.03 & 132.89 \\
\cline { 2 - 5 } & 1000 & 29.35 & 136.15 & 300.02 \\
\hline
\end{tabular}

Graph 06 shows that porosity is linearly decreases 4.08
$\%$ to $2.45 \%$ with respect to applied pressure on green pallet, and the cursing stress of specimen is linearly increases 57.89MPa to $145.94 \mathrm{MPa}$ with increase applied pressure on die for the specimen 01 manufactured under $900^{\circ} \mathrm{C}$ sintering temperature.

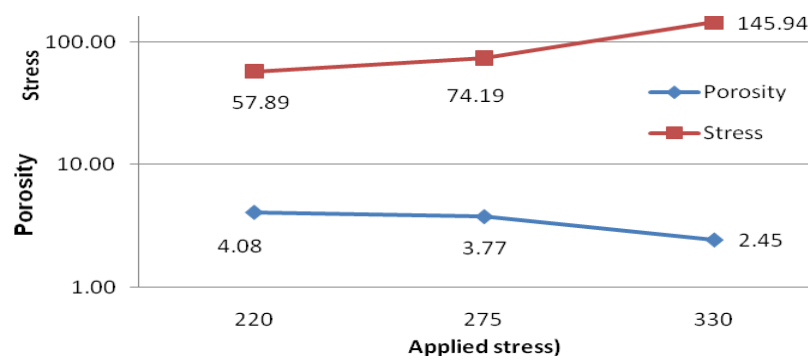

Graph 06: Porosity and crushing stress of specimen 01 for Batch-I,II \& III \& $900^{\circ} \mathrm{C}$

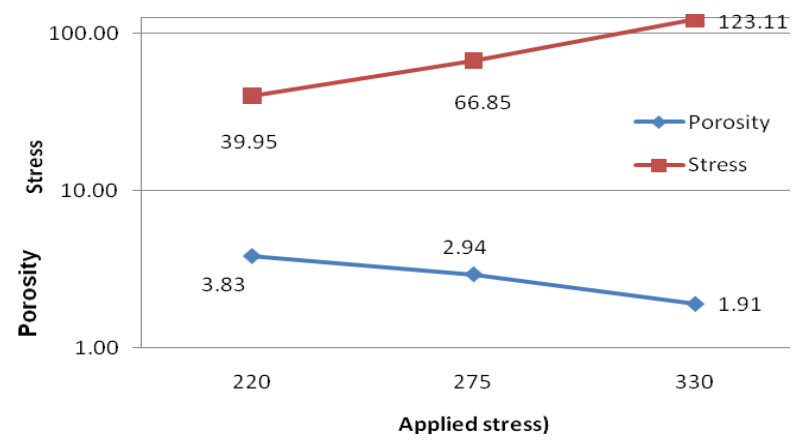

\section{Graph 07: Porosity and crushing stress of specimen 01} for Batch-I,II \& III \& $1000^{\circ} \mathrm{C}$

Graph 07 shows that porosity is linearly decreases $3.83 \%$ to $1.91 \%$ with respect to applied pressure on green pallet, and the cursing stress of specimen is linearly increases $39.95 \mathrm{MPa}$ to $123.11 \mathrm{MPa}$ with increase applied pressure on die for the specimen 01 manufactured under $1000^{\circ} \mathrm{C}$ sintering temperature.

Porosity value for specimen 01 is minimum for $1000^{\circ} \mathrm{C}$ than $900^{\circ} \mathrm{C}$ sintering temperature for all three batches, but crushing stress value is more for $900^{\circ} \mathrm{C}$ sintering temperature manufacturing condition.

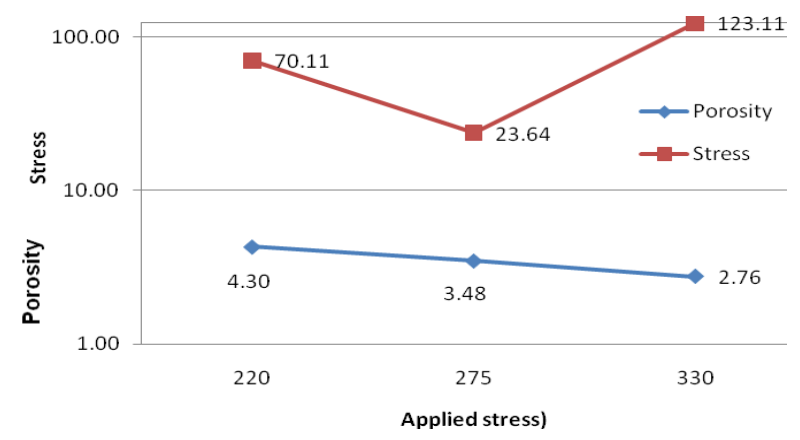

Graph 08: Porosity and crushing stress of specimen 02 for Batch-I,II \& III \& $900^{\circ} \mathrm{C}$

Published By:

Retrieval Number: C5020029320/2020@BEIESP

DOI: 10.35940/ijeat.C5020.029320

Blue Eyes Intelligence Engineering

\& Sciences Publication 


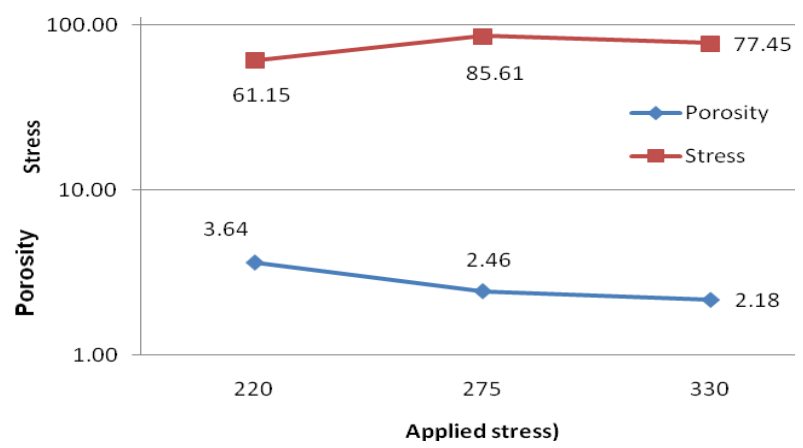

Graph 09: Porosity and crushing stress of specimen 02 for Batch-I,II \& III \& $1000^{\circ} \mathrm{C}$

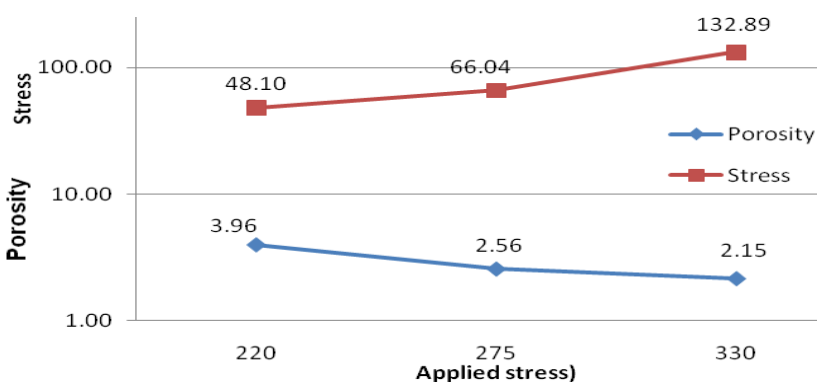

Graph 10: Porosity and crushing stress of specimen 03 for Batch-I,II \& III \& $900^{\circ} \mathrm{C}$

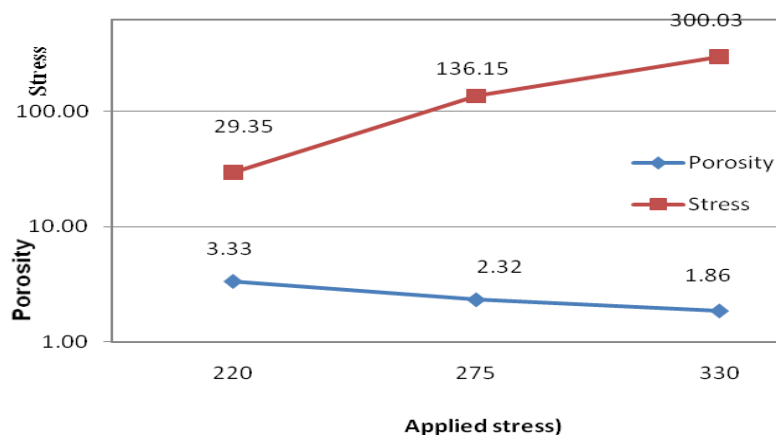

Graph 11: Porosity and crushing stress of specimen 03for Batch-I,II \& III \& $1000^{\circ} \mathrm{C}$

Trends of Graph number 08 to 11 is related relation between porosity percentages and crushing stress value is same.

\section{CONCLUSION}

In this article, mechanical properties of $\mathrm{Ni}-\mathrm{Cr}$ based composite were studied based on the effect of applied pressure on manufacturing green pallet and the effect of different sintering temperature on the proprieties of final composite material. Based on the results of the study, the following silent conclusions have been drawn.

- The studied Mechanical properties of Ni-Cr satisfy the requirement of application.

- It is observed that without varying the weight percentage of $\mathrm{Ni}-\mathrm{Cr}$ composite, it is possible to achieve mechanical properties of composite in desired range by selecting suitable pressure and sintering temperature.

- Porosity of Ni-Cr based composite material is minimum for the higher value of applied pressure and sintering temperature.

- $\quad$ Crushing strength is minimum value for highly porous composite material.

- The Hardness value of $\mathrm{Ni}-\mathrm{Cr}$ based composite material increases with decrease the porosity. Also the hardness value of composite manufactured under $900^{\circ} \mathrm{C}$ sintering specimen is low as compare to $1000^{\circ} \mathrm{C}$ sintering temperature.

- Crushing/compression stress value for $\mathrm{Ni}-\mathrm{Cr}$ based composite material is also different for $900^{\circ} \mathrm{C}$ sintering temperature and $1000^{\circ} \mathrm{C}$ sintering temperature. Crushing / compression stress also increases based on the applied pressure during green specimen.

\section{REFERENCES}

1. Shi, Xiaoliang,. "Tribological behaviors of NiAl based self-lubricating composites containing different solid lubricants at elevated temperatures." Wear 310.1-2 (2014): 1-11.

2. Ouyang, J. H., Shi, C. C., Liu, Z. G., Wang, Y. M., \& Wang, Y. J. (2015). Fabrication and high-temperature tribological properties of self-lubricating NiCr-BaMoO4 composites. Wear, 330, 272-279.

3. Zhu, S., Bi, Q., Yang, J., Liu, W., \& Xue, Q. (2011). Ni3Al matrix high temperature self-lubricating composites. Tribology International, 44(4), 445-453.

4. Liu, E. Y., Wang, W. Z., Gao, Y. M., \& Jia, J. H. (2013). Tribological properties of Ni-based self-lubricating composites with addition of silver and molybdenum disulfide. Tribology International, 57, 235-241.

5. Lu, Yan, and Zuomin Liu. "A calculated model for the porosity effect of a self-lubricating composite on its lubrication property." Tribology International 60 (2013): 169-175.

\section{AUTHORS PROFILE}

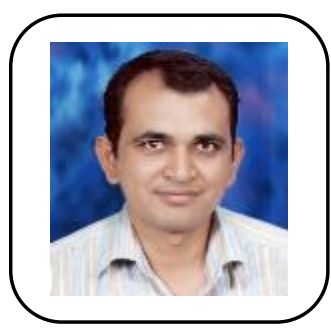

Mr. Vilas K. Patil received Master of Design from I.I.T Guwahati and currently research scholar of A.V.C.O.E Sangamner, and faculty of Mechanical Engineering Department of K.K.Wagh. I.E.E.\&R, Nashik. His research area is Agriculture Product Design, Failure Analysis, Self lubricating Composites and Solid Bearing. .

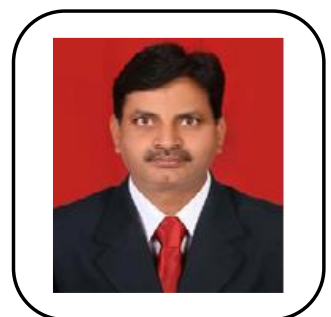

Dr. U.M.Shirsat received Ph.D. from College of Engineering Pune, Pune University. He holds the Second Ranker of Pune University at Master level in Mechanical Engineering with specialization in Design Engineering. He has twenty three year teaching experience with association of Savitribai Phule Pune University. He has presented and published sixty five technical papers in national and international conferences and journals. His research area is Fracture Mechanics, Material Properties of Ferrous and non Ferrous Material, Tribology and tool Design 